Volume 3 Issue 1, March 2019: pp. 116-131. Copyright (c) 2019 HOLREV. Faculty of Law, Halu Oleo University, Kendari, Southeast Sulawesi, Indonesia. ISSN: 2548-1762 | e-ISSN: 2548-1754. Open Access at: http://ojs.uho.ac.id/index.php/holrev/

\title{
Efektivitas Pencatatan Perkawinan Menurut Undang- Undang Nomor 1 Tahun 1974 (Studi di Kabupaten Polewali Mandar)
}

\author{
Effectiveness of Marriage Recording According to Law Number 1 Year 1974 \\ (Study in Polewali Mandar District)
}

\author{
Samsidar \\ Program Pascasarjana Universitas Muslim Indonesia \\ E-mail: imanuelmdumais@gmail.com \\ Syamsuddin Pasamai \\ Program Pascasarjana Universitas Muslim Indonesia \\ Sri Lestari Poernomo \\ Program Pascasarjana Universitas Muslim Indonesia
}

\begin{abstract}
This study aims to determine the effectiveness of marriage records in Polewali Mandar District. The approach method used in this study is normative and empirical methods. The research location was Polewali Mandar District, West Sulawesi Province. The results of the study showed that marriage registration in Polewali Mandar District was in fact already a marginal aspect of marriage. In addition to the factors marginalizing the issue of marriage registration, the views and legal awareness of the community have been relatively high regarding marital status, especially underhanded marriages which do not obtain legitimacy from ordinary people. Regarding the registration of marriage, it is known as the official marriage, which means the official marriage is a registered marriage. However, in Indonesia there are rules in the form of laws that each marriage must be recorded, and this recorded marriage can be called official marriage and legal force. Whereas unregistered marriages which are termed marriage under the hand, mean unofficial and marriage is not legally enforceable.
\end{abstract}

Keyword: Effectiveness; Marriage; Marriage Registration

Abstrak: Penelitian ini bertujuan untuk mengetahui efektivitas pencatatan perkawinan di Kabupaten Polewali Mandar. Metode pendekatan yang digunakan dalam penelitian ini adalah metode normatif dan empiris. Lokasi penelitian ialah Kabupaten Polewali Mandar, Provinsi Sulawesi Barat. Hasil penelitian menunjukkan 
bahwa pencatatan perkawinan di Kabupaten Polewali Mandar pada kenyataannya sudah merupakan aspek marginal di dalam perkawinan. Selain faktor memarginalkan persoalan pencatatan perkawinan, pandangan dan kesadaran hukum masyarakat sudah relatif tinggi mengenai status perkawinan terutama perkawinan di bawah tangan yang tidak memperoleh legitimasi dari kalangan masyarakat awam. Berkenaan dengan pencatatan perkawinan tersebut dikenal dengan istilah nikah resmi yang mana maksud dari nikah resmi itu adalah perkawinan yang tercatat. Akan tetapi di Indonesia ada aturan dalam bentuk undang-undang bahwa setiap perkawinan harus dicatat, dan perkawinan yang tercatat inilah yang dapat disebut perkawinan resmi serta berkekuatan hukum. Sedang perkawinan yang tidak tercatat yang diistilahkan dengan nikah di bawah tangan, berarti tidak resmi dan perkawinan (nikah) tersebut tidak berkekuatan hukum.

Kata kunci: Efektivitas; Perkawinan; Pencatatan Perkawinan

\section{PENDAHULUAN}

Secara historis, syariat Islam baik Al-Qur'an atau Al-Sunnah tidak mengatur secara konkret tentang adanya pencatatan perkawinan. Ini berbeda dengan muamalat (mudayanah) yang dilakukan tidak secara tunai untuk waktu tertentu, diperintahkan untuk mencatatnya. Tuntutan perkembangan, dengan berbagai pertimbangan kemaslahatan, hukum perdata Islam di Indonesia perlu mengaturnya guna kepentingan kepastian hukum di dalam masyarakat.

Pencatatan perkawinan bertujuan untuk mewujudkan ketertiban perkawinan dalam masyarakat, baik perkawinan yang dilaksanakan berdasarkan hukum Islam. Pencatatan perkawinan merupakan upaya untuk menjaga kesucian aspek hukum yang timbul dari ikatan perkawinan. Realisasi pencatatan itu, melahirkan Akta Nikah yang masing-masing dimiliki oleh istri dan suami salinannya. Akta tersebut, dapat digunakan oleh masing-masing pihak bila ada yang merasa dirugikan dari adanya ikatan perkawinan itu untuk mendapatkan haknya.

Selain hal itu, dalam Akta Nikah dilampirkan naskah perjanjian perkawinan yang biasa disebut taklik talak atau penggantungan talak, yaitu teks yang dibaca oleh suami sesudah akad nikah sebagai janji setia terhadap istrinya. Sesudah pembacaan tersebut kedua mempelai menandatangani Akta Nikah dan salinannya yang telah disiapkan oleh Pegawai Pencatat berdasarkan ketentuan yang berlaku. Setelah itu, diikuti oleh kedua saksi dan Pegawai Pencatat Nikah yang menghadiri akad nikah. Kemudian wali nikah atau yang mewakilinya, juga turut serta bertanda tangan. Dengan penandatanganan Akta Nikah 
dan salinannya, maka perkawinan telah tercatat secara yuridis normatif berdasarkan pasal 11 Peraturan Pemerintah Nomor 9 Tahun 1975 dan mempunyai kekuatan hukum berdasarkan pasal 6 ayat (2) Kompilasi Hukum Islam.

Analisa Akibat Hukum Nikah Tidak Tercatat Ditinjau dari Perspektif Gender bahwa perkawinan tidak tercatat memiliki akibat hukum yang sangat merugikan kaum wanita dan anak-anak dari perkawinan tidak tercatat tersebut. Secara hukum, perkawinan tidak tercatat hanya menempatkan perempuan dalam posisi yang rendah.

Suatu perkawinan yang tidak tercatat akan menghilangkan hak istri untuk menuntut secara hukum. Dengan kata lain, wanita tidak mendapat perlindungan hukum. Perkawinan yang demikian bertentangan dengan aspek kesetaraan gender. Karena itu menurut M. Quraish Shihab, perkawinan yang tidak tercatat merupakan salah satu bentuk pelecehan terhadap perempuan karena dapat menghilangkan hak-hak kaum perempuan. ${ }^{1}$ Pernikahan apa pun selain yang tercatat secara resmi di negara hukumnya tidak sah.

Masalah pencatatan perkawinan sejak diundangkannya Undang-Undang Nomor 32 Tahun 1954 tentang Pencatatan Nikah, Talak dan Rujuk, sampai diundangkannya UndangUndang Nomor 1 Tahun 1974 tentang Perkawinan, sudah menjadi persoalan krusial, baik oleh karena pemikiran dimana hukum negara tidak boleh berada di bawah otoritas agama, maupun oleh karena pencatatan itu sendiri sering dihubung-hubungkan dengan absahnya perkawinan.

Pencatatan perkawinan pada prinsipnya merupakan hak dasar dalam keluarga. Selain itu merupakan upaya perlindungan terhadap istri maupun anak dalam memperoleh hak-hak keluarga seperti hak waris dan lain-lain. Dalam hal nikah sirih atau perkawinan yang tidak dicatatkan dalam administrasi negara mengakibatkan perempuan tidak memiliki kekuatan hukum dalam hak status pengasuhan anak, hak waris dan hak-hak lainnya sebagai istri yang pada akhirnya sangat merugikan pihak perempuan. ${ }^{2}$

Konflik pada tingkat pembuatan aturan sebagaimana tersebut membiaskan suatu kondisi labil dalam tatanan pemahaman dan perilaku masyarakat demikian juga respons pejabat yang berwenang sampai ke tingkat yang paling bawah yaitu kecamatan dan kelurahan/desa. Urgensi pencatatan perkawinan hanya berada di bawah sub koordinasi aspek-aspek substansial bahkan terkadang tidak dipandang sebagai prosesi perkawinan.

M. Quraish Shihab, Perempuan, Jakarta: Lentera Hati, 2006, hlm. 216.

2 Achmad Sukardja, Hukum Keluarga dan Peradilan Keluarga di Indonesia, Jakarta Mahkamah Agung, 2001, tanpa halaman. 
Terdapat suatu kesan, bahwa ketaatan masyarakat untuk aktif mencatatkan perkawinannya semata-mata adalah ketaatan artifisial, dan bukan karena suatu ketaatan atas dasar kewajiban dan kebutuhan.

Dari sudut pandang komunikasi dan sosialisasi hukum, mulai dari madrasah sampai ke perguruan tinggi agama, pengajian-pengajian, dan majelis-majelis taklim, yang menjadi fokus perhatian (focus concern) dalam hal perkawinan hanyalah persoalan teknis perkawinan (syarat dan rukun perkawinan), adapun administrasi perkawinan, yang antara lain meliputi pencatatannya seolah-olah hanyalah sebagai aspek pelengkap. Orangorang akan jauh lebih merasa malu jika uang belanja yang diberikan relatif sedikit dari yang diharapkan, dibandingkan jika perkawinannya dilakukan secara di bawah tangan.

Di Sulawesi Barat pada umumnya khususnya di Kabupaten Polewali Mandar, pemahaman hukum perkawinan menurut tatanan agama bukan hanya berkisar pada sah atau tidaknya sebuah perkawinan, tetapi sudah sebahagian besar masyarakatnya sudah memahami hukum yang mempersoalkan benar atau tidaknya dari suatu perkawinan dari segi hukum positif.

Kabupaten Polewali Mandar cukup relevan untuk dijadikan obyek penelitian, sebagai salah satu barometer Provinsi Sulawesi Barat, karena hingga pertengahan tahun 2018 ini masalah pencatatan nikah yang terjadi di Kabupaten Polewali Mandar masih kurang efektif karena hingga saat ini terbukti dengan adanya kurang lebih 200 pasangan suami istri yang tidak mencatatkan perkawinannya hingga secara otomatis tidak memperoleh Buku Kutipan Akta Nikah. Tidak adanya Buku Kutipan Akta Nikah yang mereka terima maka upaya hukum yang akan mereka lakukan nantinya dalam hal pengurusan akta kelahiran, kartu keluarga dan lainnya tidak dapat dilakukan karena faktor penting dari terbitnya surat-surat atau akta tersebut berawal dari adanya Buku Kutipan Akta Nikah.

Pada sebahagian masyarakat memahami apabila perkawinan tidak tercatat sebagaimana mestinya, persoalan yang timbul bukan hanya kepada pasangan suami istri yang bersangkutan, akan tetapi juga akan menimbulkan persoalan lain di antara anak-anak yang akan dilahirkan nanti, persoalan kewarisan dan sengketa keperdataan lainnya yang melibatkan orang lain. Jika frekuensi pencatatan perkawinan efektif, maka hal itu akan menciptakan persoalan kemasyarakatan yang relatif tidak rumit terutama pada masamasa yang akan datang. 
Pencatatan perkawinan menjadi salah satu hak warga negara dimaksud adalah dengan merujuk kepada ketentuan peraturan perundang-undangan nasional Indonesia, khususnya peraturan perundang-undangan mengenai pencatatan perkawinan. Adapun yang menjadi dasar bagi setiap warga yang melangsungkan perkawinan untuk mendapatkan haknya agar perkawinannya dicatat serta mereka mendapatkan kutipan akta nikah, lalu kemudian melahirkan kewajiban bagi Negara untuk mencatat dan mengeluarkan serta memberikan kutipan akta nikah warganya, tentu jika perkawinan itu dilaksanakan sesuai aturan dan kehendak hukum negara.

Atas konstruksi hukum tersebut, perkawinan yang dilaksanakan itu merupakan perkawinan yang sah menurut kriteria hukum yang berlaku. Menurut ketentuan peraturan perundang-undangan tentang perkawinan di Indonesia (Pasal 2 Undang-Undang Perkawinan jo. Pasal 4 dan 5 Kompilasi Hukum Islam), bahwa sahnya perkawinan orang Islam itu jika mereka melaksanakannya sesuai dengan aturan hukum Islam. Lalu, suatu perkawinan yang sah menurut hukum harus dicatat. Artinya, orang yang melangsungkan perkawinan tersebut berhak mendapatkan pelayanan hukum dari negara tentang pencatatan perkawinannya.

\section{ANALISIS DAN PEMBAHASAN}

\section{Perkawinan dan Pencatatan Perkawinan dalam Perspektif Hukum}

Perkawinan menurut terminologi agama adalah "pernikahan", yaitu ikatan (akad) yang secara khusus diperuntukkan untuk sepasang suami istri dalam rangka hidup bersama, disebut "nikah", akan tetapi di Indonesia diterjemahkan dengan "perkawinan". UndangUndang yang mengaturnya disebut Undang-Undang Perkawinan.

Secara normatif, Undang-Undang Nomor 1 Tahun 1974 tentang perkawinan (disebut Undang-Undang Perkawinan) merumuskan suatu pengertian perkawinan yaitu ikatan lahir batin antara seorang pria dengan seorang wanita sebagai suami istri dengan tujuan membentuk keluarga (rumah tangga) yang bahagia dan kekal berdasarkan Ketuhanan Yang Maha Esa.

Di dalam pasal 2 dan 3 Kompilasi Hukum Islam (disebut KHI), perkawinan menurut Hukum Islam adalah pernikahan, yaitu akad yang sangat kuat atau miitsaaqon gholidhan untuk menaati perintah Allah dan melaksanakannya merupakan ibadah. Adapun tujuan perkawinan adalah untuk mewujudkan kehidupan rumah tangga yang sakinah (tenang), mawaddah (saling mengasihi), dan rahmah (saling menyayangi). 
Dalam pengertian tersebut terdapat kata "ikatan lahir batin", yaitu perikatan di dalam suatu tatanan sistem kejiwaan dan hukum, dengan tujuan membentuk keluarga yang bermuatan sakinah, mawaddah dan rahmah (tenang, dan kasih sayang), kekal (unlimited time) berdasarkan ketentuan agama yang dianut.

Konotasi suatu ikatan lahir dapat dipahami sebagai suatu perikatan yuridis, akan tetapi ikatan batin tidak ditemukan di dalam pengertian perkawinan pada umumnya, terutama dikaitkan dengan permasalahan hukum, karena ikatan tersebut memuat normanorma agama dan perasaan saling cinta mencintai antara suami istri, meskipun demikian tanpa terwujudnya suatu ikatan batin, perkawinan tidak menjadi batal.

Untuk mencapai tujuan perkawinan tersebut, maka Undang-Undang perkawinan maupun Kompilasi Hukum Islam meletakkan substansi agama sebagai dasar perkawinan. Selain itu, dalam kaitannya dengan lingkungan masyarakat, perkawinan seharusnya dilaksanakan secara tertib, baik dari segi sistem administrasi negara, maupun peraturan teknis agama yang dianut oleh pasangan suami istri.

Menurut Muhammad Amin Suma ${ }^{3}$ menyatakan bahwa paling tidak menurut sebagian ahli hukum, di antaranya Sayuti Thalib dan Mohd. Idris Ramulyo, perkawinan harus dilihat dari tiga segi pandangan, yaitu :

a. Perkawinan dari segi sosial;

b. Perkawinan dari segi agama;

c. Perkawinan dari segi hukum.

Segi sosial dari suatu perkawinan ialah bahwa dalam setiap masyarakat (bangsa), ditemui suatu penilaian yang umum bahwa orang yang berkeluarga atau pernah berkeluarga (dianggap) mempunyai kedudukan yang lebih dihargai (terhormat) dari mereka yang tidak kawin. Sedangkan dari segi sudut pandang keagamaan, perkawinan merupakan suatu hal yang dipandang suci (sakral). Karenanya tidaklah mengherankan jika semua agama pada dasarnya mengakui keberadaan institusi perkawinan.

Perkawinan sangat erat kaitannya dengan sistem kemasyarakatan, apabila perkawinan dilaksanakan sesuai dengan tatanan normatif akan menciptakan masyarakat yang kondusif. Eratnya hubungan antara keluarga di satu pihak dan masyarakat di lain pihak, tidaklah mengherankan jika masyarakat atau dalam hal ini negara banyak turut campur tangan dalam urusan keluarga ini dengan segala bentuk peraturan yang dibuatnya.

Muhammad Amin Suma, Hukum Keluarga Islam di Dunia Islam, cet. I, Jakarta: PT. Raja Grafindo Persada, 2004, hlm. 79. 
Banyaknya peraturan tersebut menunjukkan makin banyaknya keluarga mendapat perhatian negara. Walaupun akibatnya terdapat banyak pembatasan terhadap kebebasan keluarga, akan tetapi pembatasan-pembatasan itu diadakan demi kelangsungan kehidupan keluarga itu sendiri, dan ini berarti kelangsungan masyarakat atau negara dimana keluarga itu berada.

Terjadinya rumah tangga/perkawinan yang pecah, dan terutama jika hal itu banyak terjadi, akan memberikan pengaruh terhadap kehidupan masyarakat pada umumnya, sebagaimana dikemukakan John Eckelaar4:

The breakdown of a marriage ivolves more than the cessation of relationship between two individuals, for it signifies the ultimate collapse of what is the most important social group in the community.

(Terjadinya perceraian banyak disebabkan oleh karena kemudahan semu di dalam melakukan perkawinan, antara lain perkawinan yang dilaksanakan di bawah otoritas pejabat umum yang berwenang).

Dalam konteks pencatatan perkawinan, Pasal 2 ayat (2) Undang-Undang Perkawinan menyatakan bahwa tiap-tiap perkawinan dicatat menurut perundangundangan yang berlaku dan tujuan pencatatan sebagaimana yang diatur dalam Peraturan Pemerintah No. 9 Tahun 1975. Dalam Undang-Undang ini dinyatakan bahwa suatu perkawinan adalah sah bilamana dilakukan menurut hukum masing-masing agamanya dan kepercayaannya itu dan di samping itu tiap-tiap perkawinan harus dicatat menurut perundang-undangan yang berlaku.

Pencatatan tiap-tiap perkawinan adalah sama halnya dengan pencatatan peristiwaperistiwa penting dalam kehidupan seseorang misalnya kelahiran, kematian, yang dinyatakan dalam surat-surat keterangan, suatu akta resmi yang dianut dalam daftar pencatatan. Pencatatan perkawinan bukan sekedar pencatatan untuk peringatan, melainkan pencatatan yang dilakukan oleh Pegawai Pencatat Nikah pada suatu Akta Nikah.

Sejak penandatanganan pencatatan tersebut, semua orang dianggap mengetahui adanya peristiwa perkawinan. Untuk memenuhi ketentuan pencatatan tersebut, maka setiap perkawinan harus dilangsungkan di hadapan dan atau di bawah pengawasan Pegawai Pencatat Nikah, karena Kompilasi Hukum Islam (KHI), perkawinan yang dilakukan di luar pengawasan Pegawai Pencatat Nikah tidak mempunyai kekuatan hukum.

4 Lili Rasjidi, Hukum Perkawinan dan Perceraian di Malaysia dan Indonesia, Bandung: Remaja Rosdakarya, 1991, hlm 8. 
Pencatatan perkawinan yang dilakukan oleh pegawai pencatat nikah kantor urusan agama tempat perkawinan berlangsung merupakan salah satu perbuatan pejabat administrasi negara. Pejabat Pegawai Pencatat Nikah Kantor Urusan Agama tersebut merupakan hierarki dari Kementerian Agama ke eselon terendah di kecamatan, bertanggung jawab melakukan pencatatan perkawinan ke dalam sebuah akta nikah berdasarkan Daftar Pemeriksaan Nikah (disebut DPN) kemudian dituangkan ke dalam Kutipan Akta Nikah atau Duplikat Akta Nikah dan diumumkan kepada khalayak umum, sehingga pada saat penandatanganan pencatatan, menurut hukum, dianggap semua orang telah mengetahuinya.

Pencatatan di luar instansi Pegawai Pencatat Nikah Kantor Urusan Agama, meskipun bernilai administratif, akan tetapi hanya bersifat pencatatan di bawah tangan dan tidak mempunyai kekuatan hukum yang mengikat. Dengan memperhatikan ketentuan-ketentuan yang termuat di dalam Peraturan Pemerintah No. 9 Tahun 1975, terdapat beberapa tahap dalam pencatatan perkawinan yaitu: pemberitahuan, penelitian, pengumuman dan registrasi.

\section{Pemberitahuan Perkawinan}

Pasal 3 Peraturan Pemerintah No. 9 Tahun 1975 menentukan bahwa setiap orang yang akan melangsungkan perkawinan memberitahukan kehendaknya itu kepada Pegawai Pencatat Nikah di tempat perkawinan itu akan dilangsungkan. Pemberitahuan tersebut harus dilakukan sekurang-kurangnya sepuluh hari kerja sebelum perkawinan itu dilaksanakan. Pengecualian terhadap jangka waktu sepuluh hari tersebut dapat diberikan oleh camat atas nama bupati kepala daerah dengan disertai alasan penting. Lebih lanjut, Pasal 4 Peraturan Pemerintah No. 9 Tahun 1975 menyebutkan bahwa pemberitahuan itu dilakukan secara lisan atau tertulis oleh calon mempelai atau oleh orang tua atau wakilnya.

Berkenaan dengan ketentuan tersebut, pada prinsipnya kehendak untuk melangsungkan perkawinan harus dilakukan secara lisan oleh salah satu dan kedua calon mempelai, atau oleh orang tuanya atau wakilnya. Tetapi apabila karena sesuatu alasan yang sah pemberitahuan kehendak melangsungkan perkawinan secara lisan itu tidak mungkin dilakukan, maka pemberitahuan dapat dilakukan secara tertulis. Selain itu, maka yang dapat mewakili calon mempelai untuk memberitahukan kehendak melangsungkan perkawinan adalah wali atau orang lain yang ditunjuk berdasarkan kuasa khusus.

Dalam pasal 5 Peraturan Pemerintah No. 9 Tahun 1975 diatur tentang keharusan pemberitahuan itu memuat nama, umur, agama-kepercayaan, tempat kediaman calon 
mempelai, dan apabila salah seorang atau kedua-duanya kawin, disebutkan juga nama suami atau istri terdahulu. Penjelasan atas pasal tersebut menentukan selanjutnya bahwa mereka yang memiliki nama kecil dan nama keluarga hendaknya dalam pemberitahuan itu dicantumkan juga kedua nama tersebut, di samping itu masih terbuka kemungkinan penambahan pemberitahuan dengan hal-hal yang lain yang dirasakan perlu, misalnya mengenai wali nikah dan mahar (maskawin) yang akan diberikan kepada calon istri.

\section{Penelitian}

Setelah pegawai pencatat nikah menerima pemberitahuan, lalu pegawai tersebut melakukan penelitian tentang syarat-syarat perkawinan, dan kemungkinan adanya halangan perkawinan sebagaimana disebutkan di dalam Undang-Undang Perkawinan.

Pegawai pencatat nikah juga meneliti berkas yang terkait dengan kemungkinan perkawinan dilakukan di bawah umur atau karena salah seorang atau kedua calon mempelai pernah kawin. Berkas tersebut yaitu:

(1) Kutipan Akta Kelahiran atau surat kenal lahir calon mempelai, dalam hal tidak terdapat akta kelahiran atau akta kenal lahir, dapat dipergunakan surat keterangan yang menyatakan umur dan asal usul calon mempelai yang diberikan oleh kepala desa atau yang setingkat dengannya.

(2) Keterangan mengenai nama, agama-kepercayaan, pekerjaan, dan tempat tinggal orang tua calon mempelai.

(3) Penetapan pengadilan sebagai dimaksud dalam pasal 6 ayat (2), (3), dan (5) Penetapan pengadilan apabila salah seorang calon mempelai atau keduaduanya belum mencapai umur 21 tahun.

(4) Penetapan pengadilan sebagai yang dimaksudkan dalam pasal 4 UndangUndang Perkawinan dalam hal calon mempelai akan melakukan poligami.

(5) Penetapan dispensasi kawin sebagai dimaksudkan dalam pasal 7 UndangUndang Perkawinan.

(6) Surat kematian istri atau suami terdahulu atau, dalam hal terjadi perceraian, surat keterangan perceraian, bagi perkawinan kedua kalinya atau lebih.

(7) Izin tertulis dari pejabat yang ditunjuk oleh Panglima TNI atau Kapolri apabila salah seorang calon mempelai atau kedua-duanya anggota TNI dan Polri. 
(8) Surat Kuasa Otentik yang disahkan oleh Pegawai Pencatat Nikah apabila salah seorang calon mempelai atau kedua-duanya tidak dapat hadir sendiri karena sesuatu alasan penting sehingga mewakilkan kepada orang lain.

Oleh Pegawai Pencatat Nikah, hasil penelitian itu kemudian ditulis di dalam sebuah daftar yang telah disediakan. Apabila Pegawai Pencatat Nikah tersebut melihat adanya halangan atau tidak terpenuhinya syarat-syarat perkawinan, maka hal itu diberikan kepada calon mempelai, atau orang tua, atau wakil mempelai.

\section{Pengumuman}

Jika segala persyaratan tentang pemberitahuan telah terpenuhi serta hasil penelitian menunjukkan tidak terdapat halangan perkawinan, Pegawai Pencatat Perkawinan lalu menyelenggarakan pengumuman dengan cara menempelkan surat pengumuman menurut formulir yang ditentukan yang mudah dibaca oleh umum di Kantor Urusan Agama Kecamatan.

\section{Registrasi (Pencatatan)}

Pencatatan di dalam tahapan ini ialah pencatatan dalam pengertian sempit, yaitu sesuai dengan maksud pasal 11 ayat (3) Peraturan Pemerintah No. 9 Tahun 1975, yakni perkawinan dicatat resmi jika akta perkawinan telah ditandatangani oleh kedua mempelai, dua orang saksi, wali nikah dan Pegawai Pencatat Nikah, setelah itu dilakukan penandatanganan Buku Akta Nikah (Model N) yang kutipannya berupa surat nikah (Model NA).

\section{Relasi Teori Maqashid As-Syari'ah dan Tujuan Hukum Terhadap Ketentuan Pencatatan Perkawinan}

Dalam demokrasi modern, terdapat tiga cabang kekuasaan utama (primary state's organs) merujuk pada konsep separations of power, yaitu legislature, executive and judiciary, yang dialokasikan pada fungsi law making, execution and review.

Dalam konsep maqashid as-syar'iyah diharapkan segala sesuatu yang dikerjakan manusia tidak lepas dari kemaslahatan manusia itu sendiri dan manusia di sekitarnya. Oleh karena itu, segala yang tidak sejiwa dengan tujuan perbuatan baik haruslah dihindari, maka dalam hal perkawinan harus dipelihara kemaslahatan bagi orang yang melaksanakan perkawinan dan keturunannya. 
Ketentuan pencatatan perkawinan yang tujuannya untuk ketertiban dan kepastian hukum jika dikaji dengan menggunakan teori mashlahah atau maqashid as-syari'ah AsSyathibi, dapat dirumuskan sebagai berikut 5 :

a. Bahwa ketertiban adalah sebuah keniscayaan, karena Allah SWT menciptakan dan mengelola alam ini dengan penuh keteraturan, keseimbangan, keserasian, kedisiplinan serta perhitungan yang sangat detail. Begitu juga dengan perkawinan merupakan sistem yang teratur sebagai wadah bagi fitrah dua jenis manusia yang berbeda jenis kelamin dan berpasangan untuk membina keluarga bahagia. Oleh karena itu pencatatan perkawinan telah sesuai dengan semangat ajaran agama Islam.

b. Bahwa ketentuan pencatatan perkawinan tidak ditunjukkan baik secara langsung maupun tidak langsung dalam teks-teks suci (Al-Qur'an dan asSunnah), Islam dalam praktik kenabian tidak mengenal itu, sehingga sudah tepat mengkaji permasalahan ini dengan teori mashlahah atau maqashid assyari'ah karena salah satu kriteria dari teori maslahat adalah tidak adanya dalil khusus yang menunjukkannya.

c. Bahwa di zaman sekarang dengan jumlah penduduk yang semakin banyak, pendataan berupa pencatatan kependudukan baik itu kelahiran, perkawinan, perceraian, kematian dan lain-lain, mutlak diperlukan. Karena jika tidak dilakukan akan menimbulkan ketidakteraturan dan ketidaktertiban dalam kehidupan bermasyarakat, yang pada akhirnya akan menimbulkan penyelundupan hukum, dengan demikian ketentuan pencatatan perkawinan sejalan dengan maqashid as-syari'ah.

d. Bahwa dengan tidak dilakukannya pencatatan perkawinan, maka perlindungan terhadap hak-hak anggota keluarga (suami, istri dan anak) baik berupa hak atas harta, status perkawinan atau pun hak atas identitas diri, tidak bisa diperoleh, sehingga tujuan perkawinan untuk ketenteraman tidak terpenuhi, hal itu berarti tujuan primer ad-Dharury, berupa hifdz al-nasl (memelihara keturunan/kehormatan) dan hifdz al-mal (memelihara harta) tidak tercapai. Dengan demikian pencatatan perkawinan jelas menolak

5 Nurhadi, Pencatatan Perkawinan Bagi Umat Islam Menurut Teori Maqashid As-Syari'ah As-Syathibi Dan Teori Tujuan Hukum Menurut Gustav Radbruch, Hukum dan Peradilan, http://hukum-danperadilan.blogspot.co.id/2016/08/normal-0-false-false-false-in-X-none-ar.html, diakses pada tanggal 18 April 2018. 
kemudaratan/kerugian bagi anggota keluarga dan memberikan manfaat berupa perlindungan hukum atas hak seseorang.

e. Bahwa pencatatan perkawinan telah memberikan kemaslahatan/ keadilan sosial bagi seluruh masyarakat Indonesia secara umum tidak terbatas pada pribadi, agama atau golongan tertentu, oleh karena itu yang ditegakkan adalah kemaslahatan umum bukan kemaslahatan individu. Hal itu sejalan dengan kaidah fiqh: الخاصة المصلحة على مقدمة العامة المصلحة "Kemaslahatan umum (publik) harus didahulukan daripada kemaslahatan individu".

f. Bahwa secara normatif undang-undang perkawinan telah mewujudkan prinsip-prinsip yang terkandung dalam Pancasila dan Undang-Undang Dasar 1945 dan telah menampung segala kenyataan yang hidup dalam masyarakat serta telah mempertimbangkan Hukum Agama Kepercayaan dalam masyarakat, oleh karena itu seharusnya pelaksanaan ketentuan pencatatan perkawinan itu menghilangkan kesulitan masyarakat seperti terjaminnya hakhak anggota keluarga, sebaliknya tidak boleh menyulitkan masyarakat, baik dari segi biaya, waktu pengurusan, persyaratan dan lain-lain. Karena jika dalam praktiknya untuk sebagian masyarakat ternyata justru menimbulkan kesulitan, karena biaya tinggi misalnya atau karena jauhnya lokasi atau karena halangan hukum (al-man'i) lain yang tidak bisa dihindarkan, maka harus ada ketentuan alternatif lain, sehingga adanya ketentuan itu tidak merugikan masyarakat.

Berdasarkan uraian di atas, penetapan pasal 2 ayat (1) dan (2) Undang-Undang Perkawinan adalah kebijakan yang sangat tepat, karena pencatatan nikah bukan satusatunya alat bukti mengenai adanya perkawinan atau keabsahan perkawinan, karena itu, akta nikah atau pencatatan nikah adalah sebagai alat bukti tetapi bukan alat bukti yang menentukan. Karena yang menentukan keabsahan suatu perkawinan adalah perkawinan menurut agama, maka alat bukti perkawinan juga harus tidak bertentangan dengan agama. Fungsi dan kedudukan pencatatan perkawinan adalah untuk menjamin ketertiban hukum (legal order), pengakuan dan perlindungan hukum, kepastian dan kemudahan hukum.

\section{Realitas Pencatatan Sipil di Kabupaten Polewali Mandar}

Pencatatan perkawinan di Kabupaten Polewali Mandar pada kenyataannya sudah merupakan aspek marginal di dalam perkawinan, di antara perkara perceraian yang diajukan tanpa dilengkapi dengan Kutipan Akta Nikah atau Duplikatnya berbeda dengan 
aspek-aspek substansial (akad nikah, saksi-saksi nikah dan wali serta mahar) dimana pihak-pihak dan keluarga mempelai yang proaktif, demikian juga di dalam pencatatan perkawinan yang aktif bukan saja pegawai pencatat nikah (PPN) tetapi keluarga dan kedua mempelai juga aktif. Karena mereka sudah menyadari bahwa di samping perintah undangundang terlebih perintah agama melakukan pencatatan perkawinan.

Ketika seseorang akan melangsungkan perkawinan, sudah terpikirkan hal-hal yang berhubungan dengan perceraian (surat nikah umumnya dipergunakan untuk perceraian), harta yang terkumpul selama perkawinan kelak, pengurusan akta kelahiran anak yang nantinya akan lahir dalam pasangan suami istri. Hal ini memberikan pengaruh terhadap keinginan untuk mencatat perkawinan.

Masyarakat sudah mempersamakan kedudukan akta nikah dengan akta-akta lainnya, seperti akta kelahiran, akta jual beli, surat-surat tanah, kartu tanda penduduk yang secara langsung dirasakan kepentingannya di dalam lalu lintas pergaulan masyarakat, kutipan akta nikah bukan saja dipergunakan bila salah satu pihak akan mengajukan perceraian di pengadilan agama, tetapi sudah menyangkut beberapa hal, seperti pengurusan akta lahir anak, pendaftaran calon jamaah haji, pengurusan pensiunan janda anggota veteran, pencairan uang di bank apabila istri atau suami meninggal dunia yang tidak memiliki akta nikah, pengurusan uang taspen. Kenyataan tersebut sudah mempengaruhi ketergantungan pasangan suami istri untuk berurusan dengan pencatatan perkawinan.

Selain faktor memarginalkan persoalan pencatatan perkawinan, pandangan dan kesadaran hukum masyarakat sudah relatif tinggi mengenai status perkawinan terutama perkawinan di bawah tangan yang tidak memperoleh legitimasi dari kalangan masyarakat awam. Perkawinan di bawah tangan tidak dianggap sebagai salah satu alternatif solusi jika terjadi permasalahan perkawinan, misalnya kawin lari di luar nikah atau perkawinan yang tidak mendapat restu dari lingkungan keluarga.

Keyakinan dan pemahaman hukum masyarakat mengenai perlu atau tidaknya pencatatan perkawinan didasari oleh persepsi mengenai kedudukan perkawinan sebagai perikatan individual dan ketergantungannya bertumpu pada wali nikah (orang tua mempelai wanita). Jika wali nikah telah bersedia mengawinkan, dihadiri oleh saksi-saksi nikah, dan mempelai pria sanggup memberikan mahar yang layak, maka perkawinan tidak dianggap telah terwujud, tanpa melibatkan otoritas pemerintah. Perkawinan yang dilaksanakan di bawah tangan merupakan perkawinan yang terjadi di luar konstelasi 
hukum positif, karena kejadiannya berada di luar tatanan yang telah diatur secara formal di dalam undang-undang.

Mengenai perkawinan yang dilaksanakan di bawah tangan tersebut, atau tidak di hadapan pegawai pencatat nikah, dan tidak mempunyai surat nikah didasari oleh UndangUndang Nomor 1 Tahun 1974 tentang Perkawinan, Peraturan Pemerintah Nomor 9 Tahun 1975 tentang Pelaksanaan Undang-Undang Perkawinan, dan Inpres Nomor 1 Tahun 1991 tentang Kompilasi Hukum Islam. Meskipun peraturan perundang-undangan dengan tegas menyebutkan adanya sanksi, akan tetapi jika terdapat pelanggaran, sulit untuk menerapkan sanksi hukum dimaksud, terutama karena lemahnya sistem penegakan hukum (law enforcement).

Lemahnya sistem penegakan hukum tersebut tampaknya bukan merupakan kejadian yang berdiri sendiri, melainkan terkait dengan keyakinan beragama yang dianut masyarakat, bahwa perkawinan yang tidak tercatat adalah sah sepanjang dilakukan menurut ketentuan hukum agama yang dianut, dan agama yang tidak mewajibkan pencatatan perkawinan tersebut. Lemahnya sistem hukum di Kabupaten Polewali Mandar ini sehingga masih banyak permasalahan-permasalahan sehingga tidak dilakukannya pencatatan nikah pada kebanyakan masyarakat di Kabupaten Polewali Mandar, antara lain karena adanya pernikahan yang dilakukan di bawah umur, pernikahan yang dilakukan tanpa restu orang tua (kawin lari), dan pernikahan yang dilakukan karena keterpaksaan kondisi (hamil).

Atas dasar tersebut, pencatatan perkawinan sebagai salah satu dasar perkawinan relevan menjadi topik kajian masalah perkawinan yaitu dalam rangka menciptakan tertib hukum perkawinan dan meningkatkan sistem penegakan hukum (law enforcement) hukum perkawinan. Sehingga dalam peraturan perundang-undangan mengenai perkawinan di Indonesia, ada semacam arahan bahwa dalam rangka menertibkan hukum di bidang perkawinan maka setiap perkawinan yang dapat diakui sah oleh hukum agama harus dicatat.

Suatu perkawinan tidak berkekuatan hukum artinya perkawinan tersebut dalam pandangan hukum tidak pernah terjadi, sehingga tidak dapat dijadikan dasar hukum bagi peristiwa hukum lain yang timbul darinya. Atas dasar itu, perkawinan yang sebenarnya secara faktual telah dilaksanakan tidak dapat dijadikan sebagai alas hukum bagi semua peristiwa hukum yang timbul karena perkawinan tersebut. Sebab sekalipun perkawinan telah ada dan telah terjadi, akan tetapi dari sudut pandang aturan hukum yang berlaku 
perkawinan tersebut belum pernah terjadi, atau dianggap belum pernah terjadi. Dengan kata lain, suatu perkawinan yang telah dilaksanakan dianggap belum pernah terjadi sama artinya dengan tidak ada perkawinan (wujuduhu ka'adamihi). Hal ini dipahami dari ketentuan aturan-aturan hukum yang berlaku mengenai perkawinan.

Jika halnya seperti dikemukakan di atas bahwa perkawinan yang tidak tercatat tidak memiliki kekuatan hukum, dan suatu perkawinan yang tidak memiliki kekuatan hukum artinya perkawinan itu belum pernah terjadi, atau sama artinya dengan tidak ada perkawinan, maka masalah pencatatan perkawinan ini sebenarnya dapat dikatakan merupakan masalah yang sangat urgen.

Adapun urgensi dari pencatatan perkawinan dimaksud adalah terutama ketika dikaitkan dengan hak setiap warga negara, sekaligus menjadi kewajiban negara. Pertama, bahwa pelaksanaan pencatatan nikah yang terjadi di Kabupaten Polewali Mandar belum berjalan efektif karena kurangnya sosialisasi hukum pada masyarakat tentang arti penting dari pencatatan nikah tersebut; Kedua, faktor-faktor yang mempengaruhi dalam pelaksanaan pencatatan nikah di Kabupaten Polewali Mandar yaitu faktor substansi hukum, penegak hukum, kesadaran hukum masyarakat, pengetahuan hukum masyarakat, faktor ekonomi dan lingkungan.

\section{KESIMPULAN}

Masalah perkawinan di samping adalah sebagai sunah dari Rasulullah SAW dan merupakan kodrat manusia, akan tetapi perkawinan itu perlu diatur sedemikian rupa sehingga menjadi tertib dan teratur. Salah satu sarana untuk mengatur dan tertibnya lembaga perkawinan itu adalah dengan pencatatan. Pencatatan perkawinan di Kabupaten Polewali Mandar pada kenyataannya sudah merupakan aspek marginal di dalam perkawinan. Selain faktor memarginalkan persoalan pencatatan perkawinan, pandangan dan kesadaran hukum masyarakat sudah relatif tinggi mengenai status perkawinan terutama perkawinan di bawah tangan yang tidak memperoleh legitimasi dari kalangan masyarakat awam.

Berkenaan dengan pencatatan perkawinan tersebut dikenal dengan istilah nikah resmi yang mana maksud dari nikah resmi itu adalah perkawinan yang tercatat. Akan tetapi di Indonesia ada aturan dalam bentuk undang-undang bahwa setiap perkawinan harus dicatat, dan perkawinan yang tercatat inilah yang dapat disebut perkawinan resmi serta berkekuatan hukum. Sedang perkawinan yang tidak tercatat yang diistilahkan 
dengan nikah di bawah tangan, berarti tidak resmi dan perkawinan (nikah) tersebut tidak berkekuatan hukum.

\section{Daftar Pustaka}

\section{Buku}

Rasjidi, Lili, Hukum Perkawinan dan Perceraian di Malaysia dan Indonesia, Bandung: Remaja Rosdakarya, 1991.

Shihab, M. Quraish, Perempuan, Jakarta: Lentera Hati, 2006.

Sukardja, Achmad, Hukum Keluarga dan Peradilan Keluarga di Indonesia, Jakarta: Mahkamah Agung, 2001

Suma, Muhammad Amin, Hukum Keluarga Islam di Dunia Islam, cet. I, Jakarta: PT. Raja Grafindo Persada, 2004.

\section{Peraturan Perundang-Undangan}

Undang-Undang Nomor 1 Tahun 1974 Tentang Perkawinan.

Peraturan Pemerintah RI, Nomor 9 Tahun 1975, Tentang Pelaksanaan Undang-Undang Nomor 1 Tahun 1974.

Instruksi Presiden Nomor 1 tahun 1991 tentang Kompilasi Hukum Islam (KHI).

\section{Internet}

Nurhadi, Pencatatan Perkawinan Bagi Umat Islam Menurut Teori Maqashid As-Syari'ah AsSyathibi Dan Teori Tujuan Hukum Menurut Gustav Radbruch, Hukum dan Peradilan, http://hukum-dan-peradilan.blogspot.co.id/2016/08/normal-0-false-false-falsein-x-none-ar.html, diakses pada tanggal 18 April 2018. 